\title{
Mathematical Modeling of Urea Reaction with Sulfuric Acid and Phosphoric Acid to Produce Ammonium Sulfate and Ammonium Dihydrogen Phosphate Respectively
}

\author{
Juan Carlos Beltrán-Prieto * and Karel Kolomazník
}

Citation: Beltrán-Prieto, J.C.; Kolomazník, K. Mathematical Modeling of Urea Reaction with Sulfuric Acid and Phosphoric Acid to Produce Ammonium Sulfate and Ammonium Dihydrogen Phosphate Respectively. Energies 2021, 14, 8004. https://doi.org/10.3390/en14238004

Academic Editor: Aristide Giuliano

Received: 22 September 2021

Accepted: 23 November 2021

Published: 30 November 2021

Publisher's Note: MDPI stays neutral with regard to jurisdictional claims in published maps and institutional affiliations.

Copyright: (c) 2021 by the authors. Licensee MDPI, Basel, Switzerland. This article is an open access article distributed under the terms and conditions of the Creative Commons Attribution (CC BY) license (https:// creativecommons.org/licenses/by/ $4.0 /)$.
Faculty of Applied Informatics, Tomas Bata University in Zlín, Nad Stráněmi 4511, 76005 Zlín, Czech Republic; kolomaznik@utb.cz

* Correspondence: prieto@utb.cz

\begin{abstract}
Urea is the final product of protein metabolism in mammals and can be found in different biological fluids. Use of mammalian urine in agricultural production as organic fertilizer requires safe handling to avoid the formation of ammonia that will decrease the fertilizer value due to the loss of nitrogen. Safe handling is also required to minimize the decomposition of urea into condensed products such as biuret and cyanuric acid, which will also have a negative impact on the potential sustainable production of crops and sanitation technologies. The study of thermodynamics and reaction kinetics of urea stabilization plays a key role in understanding the conditions under which undesirable compounds and impurities in urea-based fertilizers and urea-based selective catalytic reduction systems are formed. For this reason, we studied the reaction of urea in acid media to achieve urea stabilization by modeling the reaction of urea with sulfuric acid and phosphoric acid, and estimating the reaction enthalpy and adiabatic heat difference for control of the heat released from the neutralization step using $\mathrm{Ca}(\mathrm{OH})_{2}$ or $\mathrm{MgO}$ for the safety of the process. Numerical and simulation analyses were performed by studying the effect of the surrounding temperature, the ratio of acid reagent to urea concentration, the rate of addition, and the reaction rate to estimate the required time to achieve an optimum value of urea conversion into ammonium dihydrogen phosphate or ammonium sulfate as potential technological opportunities for by-product valorization. Full conversion of urea was achieved in about $10 \mathrm{~h}$ for reaction rates in the order of $1 \times 10^{-5} \mathrm{~s}^{-1}$ when the ratio of $\mathrm{H}_{2} \mathrm{SO}_{4}$ to $\mathrm{CH}_{4} \mathrm{~N}_{2} \mathrm{O}$ was 1.5. When increasing the ratio to 10 , the time required for full conversion was considerably reduced to $3 \mathrm{~h}$.
\end{abstract}

Keywords: urea stabilization; mathematical modeling; simulation; enthalpy; reaction rate; adiabatic heat

\section{Introduction}

Urea $\left(\mathrm{NH}_{2} \mathrm{CONH}_{2}\right)$ is a compound that is produced in the organism through a series of enzymatic reactions occurring in the cytoplasmic matrix and mitochondria. During this catabolic process, an excess of ammonia $\left(\mathrm{NH}_{4}{ }^{+}\right)$is liberated during amino acid catabolism and protonates the conjugate base of a stronger acid $\left(\mathrm{HCO}_{3}{ }^{-}\right)$in coupled reactions to produce urea, a less toxic compound which is subsequently transported by the blood to the kidneys and excreted in the urine [1].

Urea is the main form of urinary nitrogen among the different nitrogenous constituents in the urine. The amount of urea is mainly influenced by the $\mathrm{N}$-intake. The remaining nitrogen is found to be present in other compounds such as allantoin, hippuric acid, creatinine, creatine, uric acid, xanthine, hypoxanthine, free amino acid N, and ammonia [2].

Urine has traditionally been considered as a waste product, and often contributes to environmental pollution by reducing nitrogen. Proper disposal and management are essential, particularly in places with wastewater containing urea and manure, which have the potential to be used as an alternate fertilizer for agricultural producers. This can lead to 
a positive trade balance by reducing the import of chemical fertilizers if the production process is performed at a large scale. However, if urea reacts with isocyanic acid, which is a product of urea decomposition, it can condensate to biuret, and eventually to triuret, and cyanuric acid, which are considered as undesirable impurities in urea-based fertilizers and also in urea-based selective catalytic reduction systems [3].

According to Mikkelsen [4], plant growth, protein synthesis, and internal N metabolism are affected by the presence of biuret and, although it can be mineralized by soil microorganisms, the process occurs at a slower rate than for urea. Equation (1) describes the condensation of urea into biuret. The stoichiometry reflects that the reaction is second order. In the case of small relative concentration variation, the rate can be expressed as $-\Delta \mathrm{C}_{\text {urea }} / \Delta \tau=\mathrm{kC}_{\text {urea }}{ }^{2}$.

$$
2\left(\mathrm{NH}_{2}\right)_{2} \mathrm{CO} \rightarrow\left(\mathrm{NH}_{2} \mathrm{CO}\right)_{2} \mathrm{NH}+\mathrm{NH}_{3}
$$

Urea hydrolysis by urease is required in order to obtain nitrogen urea derived for plants' uptake. The action of urease enzyme in the hydrolysis of urea is described in the following reactions [5]:

$$
\begin{gathered}
\mathrm{NH}_{2} \mathrm{CONH}_{2}+\mathrm{H}_{2} \mathrm{O} \stackrel{\text { urease }}{\longrightarrow} \mathrm{NH}_{3}+\mathrm{NH}_{2} \mathrm{COOH} \\
\mathrm{NH}_{2} \mathrm{COOH}+\mathrm{H}_{2} \mathrm{O} \rightarrow \mathrm{NH}_{3}+\mathrm{H}_{2} \mathrm{CO}_{3} \\
\mathrm{NH}_{3}+\mathrm{H}_{2} \mathrm{O} \rightarrow 2 \mathrm{HO}^{-}+2 \mathrm{NH}_{4}^{+} \\
\mathrm{H}_{2} \mathrm{CO}_{3}+2 \mathrm{HO}^{-} \rightarrow 2 \mathrm{H}_{2} \mathrm{O}+\mathrm{CO}_{3}^{2-}
\end{gathered}
$$

Generation of carbon dioxide and free volatile ammonia leads to the corresponding loss of nitrogen. Because this enzyme is ubiquitous in the environment, this process is very likely to occur. In agriculture, microorganisms present in solid excretory product and soil are responsible for enzymatic urea hydrolysis [6]. This reaction leads to environmental pollution; as a result, it is essential to stabilize urea compounds contained in the liquid residue [7].

Reactions of urea in acid or in alkali media are some of the possible means to achieve urea stabilization. The addition of acid prevents volatilization of ammonia by converting free ammonia into non-volatile ammonium. According to Equation (6), $\mathrm{NH}_{3}, \mathrm{NH}_{4}{ }^{+}$, and $\mathrm{H}^{+}$exist in equilibrium, which strongly depends on temperature, humidity, $\mathrm{NH}_{4}{ }^{+}$ concentration, and $\mathrm{pH}$. By decreasing the $\mathrm{pH}$, the equilibrium is shifted to the left, which decreases the concentration of un-ionized ammonia in the liquid, attenuating the emission of $\mathrm{NH}_{3}$. According to de Oliveira Vilela et al. [8], at $\mathrm{pH}$ lower than 7, the $\mathrm{H}^{+}$ions increase the amount of nonvolatile $\mathrm{NH}_{4}{ }^{+}$while decreasing the quantity of volatile $\mathrm{NH}_{3}$. This is the basic principle behind acidification of waste slurries to diminish emissions of $\mathrm{NH}_{3}$ during storage. Accordingly, increasing the temperature affects the dissociation constant $\left(\mathrm{K}_{\mathrm{d}}\right)$ and the fraction of un-ionized ammonia increases. Equation (7) represents the estimation of $K_{d}$ for dilute aqueous solutions at $25^{\circ} \mathrm{C}$ [9]:

$$
\begin{gathered}
\mathrm{NH}_{4}{ }_{(1)} \rightleftarrows \mathrm{NH}_{3(1)}+\mathrm{H}^{+} \\
\mathrm{K}_{\mathrm{d}}=\frac{\left[\mathrm{NH}_{3(1)}\right]\left[\mathrm{H}^{+}\right]}{\left[\mathrm{NH}_{4}{ }^{+}(1)\right]}=5.6 \times 10^{-10}
\end{gathered}
$$

Urea can be also stabilized in alkali media to prevent enzymatic hydrolysis. Simha et al. reported the alkaline dehydration of fresh urine using $\mathrm{MgO}$ and $\mathrm{MgO}$ mixed with biochar, wheat bran, or calcium hydroxide at $50^{\circ} \mathrm{C}$. Co-substrates were used to facilitate the disintegration of the peptide layer over the surface of urine, which limited the evaporative removal of water. In this process, urine was dried to produce a solid fertilizer. A concentration of $2 \mathrm{~g} \cdot \mathrm{L}^{-1} \mathrm{MgO}$ was necessary to achieve saturation and to increase the $\mathrm{pH}$ to a 
value of 10 and to inhibit the enzyme-catalyzed hydrolytic degradation of urea [10]. It was suggested to avoid higher temperatures, because this could lead to the reactivation of urease, as more than $40^{\circ} \mathrm{C}$ decreased the saturation $\mathrm{pH}$ to $<10$.

The decomposition of urea in aqueous media was studied previously by Shaw and Bordeaux [11], using the method of initial rates to estimate the entropy and activation energy at different values of acid concentration and ionic strength. They found that the reaction with respect to urea was of first order and that the presence of acid promoted the inhibition of urea decomposition, rather than acting as a catalyst. Additionally, reaction rates in water alone were lower than in acid due to higher ionic strength of the acid solution. Activation energies of 32.7 and $32.4 \mathrm{kcal}$ were obtained using solutions of $50 \mathrm{mM} \mathrm{H}_{2} \mathrm{SO}_{4}$ and $\mathrm{H}_{2} \mathrm{O}$, respectively. They reported values of the rate constant between $2 \times 10^{-7} \mathrm{~s}^{-1}$ $\left(60^{\circ} \mathrm{C}\right)$ and $4.15 \times 10^{-5} \mathrm{~s}^{-1}\left(100^{\circ} \mathrm{C}\right)$.

Urea is widely used in soil and foliar applications, providing benefits in agricultural production. The principal use of urea in agriculture is to provide nitrogen for soil fertilizer formulations. Fertilizers containing N, P, and K are important because these elements are in lower concentrations in soils and are also rapidly depleted once the plant is removed during the harvesting season. As a result, gradual addition of these elements to the soil helps to promote fertility. Some organic materials that are generally used to incorporate these required elements are manure, compost, and treated sewage sludge [12]. However, the use of urea-derived compounds in agricultural production faces some challenges, mainly in terms of $\mathrm{NH}_{3}$ volatilization, Nitrogen dioxide accumulation and phytotoxicity problems have been associated with adverse effects on seed germination and seedling growth in the presence of $\mathrm{NH}_{3}$ [13]. Some of the studies concerning the production of urea derivatives with application as fertilizers include research by Biskupsi et al. [14] who reported a continuous process for the manufacturing of urea-superphosphate and phosphate fertilizers based on the decomposition of phosphate raw materials with urea solutions (1.5-4 mol) in acid media, and using $90 \%$ to $100 \%$ with respect of the stoichiometric requirement to achieve complete decomposition of the rock phosphate. They stressed the importance of the possibility of occurrence of exothermic reactions, which could represent a threat to the safety of the process and leading eventually to injury, loss of life, or damage to instruments and property. The main reactions that gave rise to a safety threat were the exothermic urea hydrolysis reaction, including neutralization of released ammonia in the presence of mineral acids $\left(\mathrm{H}_{2} \mathrm{SO}_{4}\right.$ and $\left.\mathrm{H}_{3} \mathrm{PO}_{4}\right)$ and exothermic reactions that lead to the formation of amide compounds. Another study reported the reaction of $\mathrm{H}_{3} \mathrm{PO}_{4}$ with urea and ammonia to obtain solid and liquid concentrated fertilizers based on ammonium and urea polyphosphates containing $\mathrm{N}, \mathrm{P}$, and $\mathrm{K}$ through ammoniation and condensation of urea phosphate, which favored the separation of the impurities such as iron, aluminum, calcium, magnesia, and fluorine that were present in the liquid phase. Accordingly, the products obtained could be utilized after dissolution in water, by spraying, injection, sprinkling, or dilution as other common and commercial fertilizers [15]. Additional works have reported the manufacturing of stable products containing mono and diurea sulfates free of sulfamic acid and ammonium sulfamate produced from the reaction between concentrated urea and sulfuric acid used in stoichiometric quantities [16].

Thermal decomposition of urea $\left(>130^{\circ} \mathrm{C}\right)$ has been studied previously using different analytical methods, i.e., thermogravimetric analysis (TG), differential scanning calorimetry (DSC), ammonium ion-selective electrode (ISE), high performance liquid chromatography (HPLC), and Fourier transform-infrared (FT-IR) spectroscopy [17]. It has been reported that this process can lead to a diversity of undesired intermediates and by-products, namely cyanic acid, ciamelide, cyanuric acid, ammelide, melamine, biuret, and triuret, among others [18-21]. For this reason, it is important to ensure that the proposed technologies for wastewater treatment containing urea avoid raising temperatures to higher levels. Taking this into consideration, we approach the stabilization of urea in acid media, modeling the reaction of urea with sulfuric acid and urea with phosphoric acid and estimating the enthalpy of the reaction and the adiabatic heat difference. 
Stream effluents from wastewater originated in farms and companies that focus on agricultural production are characterized for containing urea, organic matter, and high values of oxidizable organic matter. These effluents have to be treated before final disposal in order to remove colloidal suspended solids and improve water quality. Particularly, in the case of effluents that contain urea, an additional benefit can be explored if the sedimentation allows the formation of compounds with added value such as fertilizers. Additionally, the separated water can be recycled in the premises of the company and used in operations that do not require high levels of purity. Efficient use of water resources is important because critical drought periods have limited the supply of water, leading to an increment in operational costs. The proposal of a technology that promotes the reuse of water while favoring the formation and separation of high value-added compounds from the wastewater is a solution approach that will benefit this type of company. In this research, we aimed to study the reaction of urea with mineral acids to support urea stabilization by describing the mathematical modeling of such a process and estimating the enthalpy of the exothermic reaction and the adiabatic heat difference, which is particularly important for the safety of the process. We also performed sedimentation tests to evaluate the rate of settlement using $\mathrm{H}_{3} \mathrm{PO}_{4}$ and $\mathrm{H}_{2} \mathrm{SO}_{4}$ to promote the formation of a coagulated solid phase that can be used as a valuable organic nitrogen fertilizer.

\subsection{Role of Sulfur in Plants}

Sulfur is one of the chemical elements required in large amounts by plants $\left(>1000 \mathrm{mg} \cdot \mathrm{kg}^{-1}\right)$; however, in order to be absorbed through the root system it is required to be in the form of sulfate. The reaction of urea with sulfuric acid leads to the generation of ammonium sulfate, a compound that is generally used as fertilizer containing $21 \%$ of $\mathrm{N}$ and $24 \%$ of $\mathrm{S}$, which is normally incorporated within the irrigation water by the drip system and also through direct soil application. It is quickly absorbed by the plant and can be used alone or in a mixture combined with other fertilizers. Once absorbed by the roots, it allows sulfur to be incorporated into the structure of o-acetylserine, which eventually contributes to the formation of L-cysteine by a complex variety of isoforms that are present in the cytosol, chloroplasts, and mitochondria [22]. The most significant sources of $S$ are ammonium sulfate, single superphosphate, and potassium sulfate. Sulfur concentration in plant tissues varies between 0.1 and $0.5 \%$ [23]. For most common crops, $\mathrm{SO}_{4}{ }^{-2}$ concentrations of 3-5 ppm are sufficient, except for rapeseed/canola, alfalfa, and broccoli, which require higher concentration. Deficiency of sulfur in the soil has been associated with reduced plant growth, occurrence of uniform yellowing of leaf tissue due to a lack of chlorophyll on younger leaves, reduction in $\mathrm{N}$ and $\mathrm{P}$ fixation by affecting nodule development and function, and accumulation of nonprotein $\mathrm{N}$ as $\mathrm{NH}_{2}$ and $\mathrm{NO}_{3}{ }^{-}$in leaves. This affects the optimum N:S ratio needed for effective $\mathrm{N}$ use by rumen microorganisms and reduces food quality [24].

Sulfur compounds are also used as fungicides, particularly to prevent fungal spores from germinating, and against powdery mildew, rose black spot, rusts, and other diseases. During the nitrification process, the conversion of $\mathrm{NH}_{4}{ }^{+}$to $\mathrm{NO}_{3}{ }^{-}$liberates $\mathrm{H}^{+}$and reduces the alkalinity of the soil. This can be explained thorough Equations (8)-(10). It can be seen that ammonium sulfate generates double the amount of $\mathrm{H}^{+}$in comparison to urea or ammonium nitrate and promotes acidification. As a result, this creates a favorable environment to keep other elements in solution, such as $\mathrm{P}, \mathrm{Fe}, \mathrm{Zn}, \mathrm{B}, \mathrm{Cu}$, and Mn, especially in cases of alkaline soils, and increases its availability and further absorption.

$$
\begin{gathered}
\left(\mathrm{NH}_{4}\right)_{2} \mathrm{SO}_{4}+4 \mathrm{O}_{2} \rightarrow 4 \mathrm{H}^{+}+2 \mathrm{NO}_{3}^{-}+\mathrm{SO}_{4}{ }^{2-}+2 \mathrm{H}_{2} \mathrm{O} \\
\left(\mathrm{NH}_{2}\right)_{2} \mathrm{CO}+4 \mathrm{O}_{2} \rightarrow 2 \mathrm{H}^{+}+2 \mathrm{NO}_{3}^{-}+\mathrm{CO}_{2}+2 \mathrm{H}_{2} \mathrm{O} \\
\mathrm{NH}_{4} \mathrm{NO}_{3}+2 \mathrm{O}_{2} \rightarrow 2 \mathrm{H}^{+}+2 \mathrm{NO}_{3}^{-}+\mathrm{H}_{2} \mathrm{O}
\end{gathered}
$$




\subsection{Importance of Phosphorous in Plant}

Diffusion and mass flow contribute to the transport of $\mathrm{P}$ from the soil to the root surface. The main role of $\mathrm{P}$ in the plant is to participate in membrane transport, and energy storage and transfer. After plants perform the photosynthesis process, carbohydrates and phosphate compounds are required for plant growth and the reproductive process. Phosphorous is present in ATP and ADP molecules, which actively participate in biosynthesis of proteins, phospholipids, and nucleic acids. When $\mathrm{P}$ is in low concentrations, growth and development is restricted [24]. Experiments in the field have been performed in soil with a low concentration of phosphorus. In such cases, several N, P, NP, and NPS fertilizers were applied. It was observed that a very low yield was obtained in the control treatment and the treatment with nitrogen alone. However, when phosphorus was applied, seeds' yield increased dramatically. The best results were obtained with a mixture of urea, elemental sulfur, and a natural phosphate obtained from a marine sediment, followed by ammonium phosphate [25].

\section{Materials and Methods}

\subsection{Stabilization of Urea with Sulfuric Acid}

For the analysis of reaction between sulfuric acid and urea we consider that the following reaction takes place:

$$
\mathrm{CH}_{4} \mathrm{~N}_{2} \mathrm{O}+\mathrm{H}_{2} \mathrm{SO}_{4}+\mathrm{H}_{2} \mathrm{O} \rightarrow\left(\mathrm{NH}_{4}\right)_{2} \mathrm{SO}_{4}+\mathrm{CO}_{2}
$$

Equation (11) describes that the rate of formation of ammonium sulfate is proportional both to the concentration of urea and to the concentration of sulfuric acid. The concentration of urea and sulfuric acid can be determined by the following model:

$$
-\frac{\mathrm{dC}_{\mathrm{CH}_{4} \mathrm{~N}_{2} \mathrm{O}}}{\mathrm{d} \tau}=-\frac{\mathrm{dC}_{\mathrm{H}_{2} \mathrm{SO}_{4}}}{\mathrm{~d} \tau}=\mathrm{k} \cdot \mathrm{C}_{\mathrm{CH}_{4} \mathrm{~N}_{2} \mathrm{O}} \cdot \mathrm{C}_{\mathrm{H}_{2} \mathrm{SO}_{4}}
$$

The use of concentration in the description of the reaction rate rather than the amount of substance makes the rate an intensive property or independent of the system size. The amount of $\mathrm{CH}_{4} \mathrm{~N}_{2} \mathrm{O}$ and $\mathrm{H}_{2} \mathrm{SO}_{4}$ that reacts at any time $(\tau)$ is $\mathrm{C}_{\left(\mathrm{CH}_{4} \mathrm{~N}_{2} \mathrm{O}\right)_{0}} \cdot \mathrm{X}_{\mathrm{CH}_{4} \mathrm{~N}_{2} \mathrm{O} \text { where }}$ $\mathrm{X}_{\mathrm{CH}_{4} \mathrm{~N}_{2} \mathrm{O}}$ represents the conversion of $\mathrm{CH}_{4} \mathrm{~N}_{2} \mathrm{O}$. Then, in terms of $\mathrm{X}_{\mathrm{CH}_{4} \mathrm{~N}_{2} \mathrm{O}}$, we have:

$$
\begin{aligned}
& \mathrm{C}_{\left(\mathrm{CH}_{4} \mathrm{~N}_{2} \mathrm{O}\right)_{0}} \frac{\mathrm{dC}_{\mathrm{CH}_{4} \mathrm{~N}_{2} \mathrm{O}}}{\mathrm{d} \tau}=\mathrm{k} \cdot\left[\mathrm{C}_{\left(\mathrm{CH}_{4} \mathrm{~N}_{2} \mathrm{O}\right)_{0}}-\mathrm{C}_{\left(\mathrm{CH}_{4} \mathrm{~N}_{2} \mathrm{O}\right)_{0}} \mathrm{X}_{\mathrm{CH}_{4} \mathrm{~N}_{2} \mathrm{O}}\right]\left[\mathrm{C}_{\left(\mathrm{H}_{2} \mathrm{SO}_{4}\right)_{0}}-\mathrm{C}_{\left(\mathrm{CH}_{4} \mathrm{~N}_{2} \mathrm{O}\right)_{0}} \mathrm{X}_{\mathrm{CH}_{4} \mathrm{~N}_{2} \mathrm{O}}\right] \\
& \mathrm{C}_{\left(\mathrm{CH}_{4} \mathrm{~N}_{2} \mathrm{O}\right)_{0}} \frac{\mathrm{dC}_{\mathrm{CH}_{4} \mathrm{~N}_{2} \mathrm{O}}}{\mathrm{d} \tau}=\mathrm{k} \cdot \mathrm{C}_{\left(\mathrm{CH}_{4} \mathrm{~N}_{2} \mathrm{O}\right)_{0}}{ }^{2}\left[1-\mathrm{X}_{\left.\mathrm{CH}_{4} \mathrm{~N}_{2} \mathrm{O}\right]}\left[\frac{\mathrm{C}_{\left(\mathrm{H}_{2} \mathrm{SO}_{4}\right)_{0}}}{\mathrm{C}_{\left(\mathrm{CH}_{4} \mathrm{~N}_{2} \mathrm{O}\right)_{0}}}-\mathrm{X}_{\mathrm{CH}_{4} \mathrm{~N}_{2} \mathrm{O}}\right]\right. \\
& \int_{0}^{\mathrm{X}_{\mathrm{CH}_{4} \mathrm{~N}_{2} \mathrm{O}}} \frac{\mathrm{dC}_{\mathrm{CH}_{4} \mathrm{~N}_{2} \mathrm{O}}}{\left[1-\mathrm{X}_{\left.\mathrm{CH}_{4} \mathrm{~N}_{2} \mathrm{O}\right]}\right]\left[\frac{\mathrm{C}_{\left(\mathrm{H}_{2} \mathrm{SO}_{4}\right)_{0}}}{\mathrm{C}_{\left(\mathrm{CH}_{4} \mathrm{~N}_{2} \mathrm{O}\right)_{0}}}-\mathrm{X}_{\mathrm{CH}_{4} \mathrm{~N}_{2} \mathrm{O}}\right]}=\mathrm{kC}_{\left(\mathrm{CH}_{4} \mathrm{~N}_{2} \mathrm{O}\right)_{0}} \int_{0}^{\tau} \mathrm{d} \tau
\end{aligned}
$$

As expressed in Equation (15), the limits of integration are taken as $\mathrm{X}_{\mathrm{CH}_{4} \mathrm{~N}_{2} \mathrm{O}}=0$ at $\tau=0$ and $\mathrm{X}_{\mathrm{CH}_{4} \mathrm{~N}_{2} \mathrm{O}}=\mathrm{X}_{\mathrm{CH}_{4} \mathrm{~N}_{2} \mathrm{O}}$ at $\tau=\tau$. The integral on the left side of the equation can be solved using the partial fraction decomposition method, which implies writing this expression as a sum of two simple terms, and eventually leading to Equation (16):

$$
\frac{-\ln \left|1-\mathrm{X}_{\mathrm{CH}_{4} \mathrm{~N}_{2} \mathrm{O}}\right|}{\left[\frac{\mathrm{C}_{\left(\mathrm{H}_{2} \mathrm{SO}_{4}\right)_{0}}}{\mathrm{C}_{\left(\mathrm{CH}_{4} \mathrm{~N}_{2} \mathrm{O}\right)_{0}}}-1\right]}-\frac{\ln \left|\frac{\mathrm{C}_{\left(\mathrm{H}_{2} \mathrm{SO}_{4}\right)_{0}}}{\mathrm{C}_{\left(\mathrm{CH}_{4} \mathrm{~N}_{2} \mathrm{O}\right)_{0}}}-\mathrm{X}_{\mathrm{CH}_{4} \mathrm{~N}_{2} \mathrm{O}}\right|-\ln \left|\frac{\mathrm{C}_{\left(\mathrm{H}_{2} \mathrm{SO}_{4}\right)_{0}}}{\mathrm{C}_{\left(\mathrm{CH}_{4} \mathrm{~N}_{2} \mathrm{O}\right)_{0}}}\right|}{1-\frac{\mathrm{C}_{\left(\mathrm{H}_{2} \mathrm{SO}_{4}\right)_{0}}}{\mathrm{C}_{\left(\mathrm{CH}_{4} \mathrm{~N}_{2} \mathrm{O}\right)_{0}}}}=\mathrm{kC}_{\left(\mathrm{CH}_{4} \mathrm{~N}_{2} \mathrm{O}\right)_{0}} \tau
$$


After simplification and using properties of logarithms, the following expression is obtained:

$$
\mathrm{X}_{\mathrm{CH}_{4} \mathrm{~N}_{2} \mathrm{O}}=\frac{\frac{\mathrm{C}_{\left(\mathrm{H}_{2} \mathrm{SO}_{4}\right)_{0}}}{\mathrm{C}_{\left(\mathrm{CH}_{4} \mathrm{~N}_{2} \mathrm{O}\right)_{0}}}\left\{\mathrm{e}^{\mathrm{kC}_{\left(\mathrm{CH}_{4} \mathrm{~N}_{2} \mathrm{O}\right)_{0}} \tau\left[\frac{\mathrm{C}_{\left(\mathrm{H}_{2} \mathrm{SO}_{4}\right)_{0}}}{\mathrm{C}_{\left(\mathrm{CH}_{4} \mathrm{~N}_{2} \mathrm{O}\right)_{0}}}-1\right]}-1\right\}}{\frac{\mathrm{C}_{\left(\mathrm{H}_{2} \mathrm{SO}_{4}\right)_{0}}}{\mathrm{C}_{\left(\mathrm{CH}_{4} \mathrm{~N}_{2} \mathrm{O}\right)_{0}}} \mathrm{e}^{\mathrm{kC}_{\left(\mathrm{CH}_{4} \mathrm{~N}_{2} \mathrm{O}\right)_{0}} \tau\left[\frac{\mathrm{C}_{\left(\mathrm{H}_{2} \mathrm{SO}_{4}\right)_{0}}}{\mathrm{C}_{\left(\mathrm{CH}_{4} \mathrm{~N}_{2} \mathrm{O}\right)_{0}}}-1\right]}-1}
$$

This equation represents the conversion of urea. Due to the very good solubility of urea in water $\left(108 \mathrm{~g} / 100 \mathrm{~mL}\right.$ at $\left.20^{\circ} \mathrm{C}\right)$ it can be assumed that the dissolution rate will not be a key reaction. However, in the application for agricultural production, urea is often used as a support component in foliar fertilizer mixtures that are applied to provide a resistance effect, and its concentration is usually less than $1 \%$. This kinetic description is proposed for highly diluted urea solutions as the solid urea would also introduce kinetics of reaction between solid and liquid phases and dissolving of solid in water contained in the acid.

An example of the application of Equation (17) is given next. We proceed to analyze 4 different numerical cases. The first case is when the ratio of $\mathrm{C}_{\left(\mathrm{H}_{2} \mathrm{SO}_{4}\right)_{0}} / \mathrm{C}_{\left(\mathrm{CH}_{4} \mathrm{~N}_{2} \mathrm{O}\right)_{0}}=1.5$, and $\mathrm{C}_{\left(\mathrm{CH}_{4} \mathrm{~N}_{2} \mathrm{O}\right)_{0}}=1$, which leads to Equation (18) to determine the conversion of urea:

$$
\mathrm{X}_{\mathrm{CH}_{4} \mathrm{~N}_{2} \mathrm{O}}=\frac{1.5\left[\mathrm{e}^{0.5 \cdot \mathrm{k} \tau}-1\right]}{1.5 \mathrm{e}^{0.5 \cdot \mathrm{k} \tau}-1}
$$

Numerical analysis is performed to determine the expected time required to achieve an optimum value of urea conversion. We used a maximum value of rate constant equal to $4.5 \times 10^{5} \mathrm{~s}^{-1}$ because it is a value reported previously by Shaw and Bordeaux during the decomposition of urea in acid media. This can be observed in Figure 1. In the case of reaction rates $<4.5 \times 10^{-5} \mathrm{~s}^{-1}$, full conversion requires more than $20 \mathrm{~h}$. A second case is analyzed in which 3 times more $\mathrm{H}_{2} \mathrm{SO}_{4}$ is added, that is: $\mathrm{C}_{\left(\mathrm{H}_{2} \mathrm{SO}_{4}\right)_{0}} / \mathrm{C}_{\left(\mathrm{CH}_{4} \mathrm{~N}_{2} \mathrm{O}\right)_{0}}=3$, and $\mathrm{C}_{\left(\mathrm{CH}_{4} \mathrm{~N}_{2} \mathrm{O}\right)_{0}}=1$. Conversion of urea can then be estimated according to Equation (19):

$$
\mathrm{X}_{\mathrm{CH}_{4} \mathrm{~N}_{2} \mathrm{O}}=\frac{3\left[\mathrm{e}^{2 \cdot \mathrm{k} \tau}-1\right]}{3 \mathrm{e}^{2 \cdot \mathrm{k} \tau}-1}
$$

We also analyzed the case when the concentration of $\mathrm{H}_{2} \mathrm{SO}_{4}$ added is half the initial concentration of urea, that is: $\mathrm{C}_{\left(\mathrm{H}_{2} \mathrm{SO}_{4}\right)_{0}} / \mathrm{C}_{\left(\mathrm{CH}_{4} \mathrm{~N}_{2} \mathrm{O}\right)_{0}}=0.5$, and $\mathrm{C}_{\left(\mathrm{CH}_{4} \mathrm{~N}_{2} \mathrm{O}\right)_{0}}=1$. Then, we studied the case of urea conversion considering a constant value of $\mathrm{k}=4.5 \times 10^{-5} \mathrm{~s}^{-1}$, with different ratios of $\mathrm{H}_{2} \mathrm{SO}_{4}$ and $\mathrm{CH}_{4} \mathrm{~N}_{2} \mathrm{O}$, with $0 \leq \mathrm{C}_{\left(\mathrm{H}_{2} \mathrm{SO}_{4}\right)_{0}} / \mathrm{C}_{\left(\mathrm{CH}_{4} \mathrm{~N}_{2} \mathrm{O}\right)_{0}} \geq 10,0 \leq \tau \geq 3 \mathrm{~h}$.

To visualize the conversion-time relations most efficiently, it is useful to consider plots of $\mathrm{X}_{\mathrm{CH}_{4} \mathrm{~N}_{2} \mathrm{O}}$ as a function of $\tau$ for various values of reaction rates as described in Figure 1 . We can observe that the maximum value in conversion shifts to smaller $\tau$ as $k$ becomes larger. Accordingly, the maximum also becomes less pronounced as $\mathrm{k}$ becomes larger.

According to the stoichiometry of the reaction, it is also possible to know the formation of $\left(\mathrm{NH}_{4}\right)_{2} \mathrm{SO}_{4}$ by following the conversion of urea. Regarding the ammonium sulfate concentration, the rate of formation is slow at lower times. It is possible to observe a change in the slope of the conversion curves as the ratio between the amount of sulfuric acid and initial concentration of urea increases. At lower values of the rate constant, the conversion continues to increase significantly as time continues. 

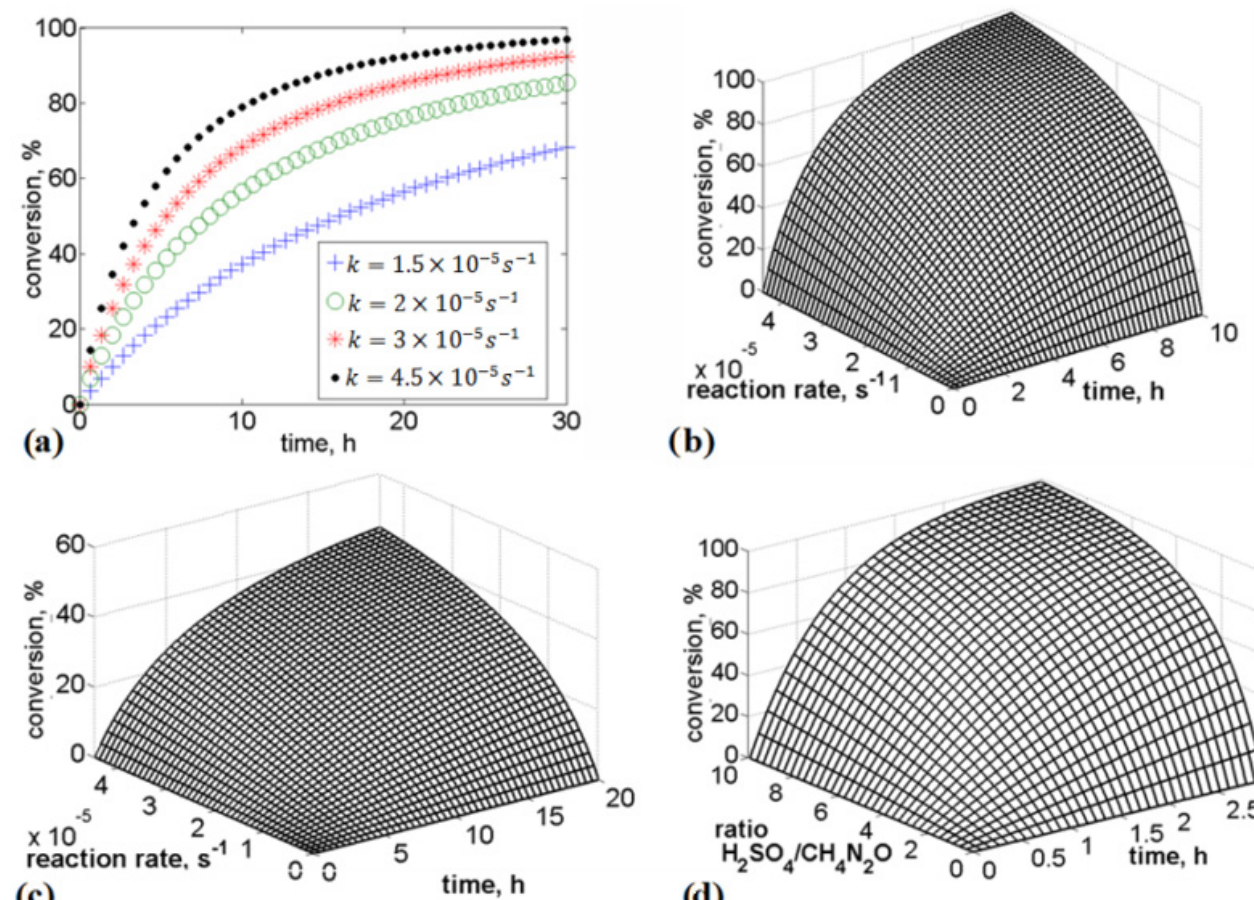

(b)

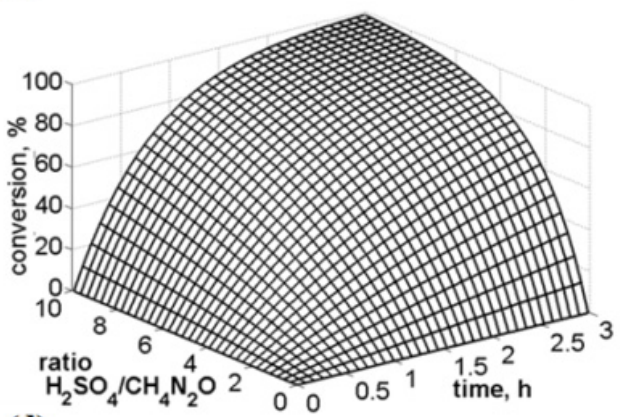

(d)

Figure 1. (a) Time evolution of urea conversion according to the corresponding values of reaction rate.

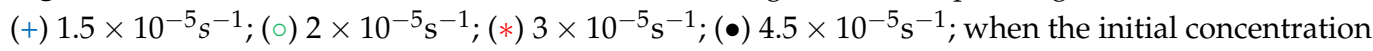
of $\mathrm{H}_{2} \mathrm{SO}_{4}$ is 1.5 times higher than the initial concentration of urea. (b) Numerical simulation of urea conversion at different reaction rates values when the initial concentration of $\mathrm{H}_{2} \mathrm{SO}_{4}$ is 3 times higher than the initial concentration of urea. (c) Numerical simulation of urea conversion considering different possible values of reaction rates when the initial concentration of $\mathrm{H}_{2} \mathrm{SO}_{4}$ is half the initial concentration of urea. (d) Numerical simulation of urea conversion at different values of $\mathrm{C}_{\left(\mathrm{H}_{2} \mathrm{SO}_{4}\right)_{0}} / \mathrm{C}_{\left(\mathrm{CH}_{4} \mathrm{~N}_{2} \mathrm{O}\right)_{0}}$ ratio with a rate constant vale equal to $4.5 \times 10^{-5} 0.001 \mathrm{~s}^{-1}$.

\subsection{Estimation of Adiabatic Heat Difference}

Estimation of adiabatic heat difference was performed on the basis of practical application, considering the case of a tank containing $30 \mathrm{~m}^{3}$ of wastewater containing diluted urine to which $217 \mathrm{~kg}$ of $\mathrm{H}_{2} \mathrm{SO}_{4}$ was added. The concentration of diluted acid $\left(\mathrm{a}_{\mathrm{H}_{2} \mathrm{SO}_{4}}\right)$ was estimated according to Equation (20) where $\mathrm{m}_{\mathrm{H}_{2} \mathrm{SO}_{4}}$ and $\mathrm{m}_{\mathrm{H}_{2} \mathrm{O}}$. corresponds to the initial mass of $\mathrm{H}_{2} \mathrm{SO}_{4}$ and wastewater respectively, and corresponds to $0.7 \%$ :

$$
\mathrm{a}_{\mathrm{H}_{2} \mathrm{SO}_{4}}=\frac{\mathrm{m}_{\mathrm{H}_{2} \mathrm{SO}_{4}}}{\mathrm{~m}_{\mathrm{H}_{2} \mathrm{SO}_{4}}+\mathrm{m}_{\mathrm{H}_{2} \mathrm{O}}}
$$

The adiabatic heat difference is calculated after Equation (21) where $\Delta \mathrm{H}_{\mathrm{dil}}^{\mathrm{H}_{2} \mathrm{SO}_{4}}$ is the enthalpy of diluted $\mathrm{H}_{2} \mathrm{SO}_{4}\left(972 \mathrm{~kJ} \cdot \mathrm{kg}^{-1}\right), \mathrm{Cp}$ is the specific heat of water $\left(4.18 \mathrm{~kJ} \cdot \mathrm{kg}^{-1} \cdot \mathrm{K}^{-1}\right)$. This leads to a value of $\Delta \mathrm{t}=1.63{ }^{\circ} \mathrm{C}$.

$$
\Delta \mathrm{t}=\frac{\mathrm{a}_{\mathrm{H}_{2} \mathrm{SO}_{4}} \times \Delta \mathrm{H}_{\mathrm{dil}}^{\mathrm{H}_{2} \mathrm{SO}_{4}}}{\mathrm{Cp}}
$$

\subsection{Neutralization Using $\mathrm{Ca}(\mathrm{OH})_{2}$}

Because the $\mathrm{H}_{2} \mathrm{SO}_{4}$ need to be neutralized with $\mathrm{Ca}(\mathrm{OH})_{2}$, we proceed to estimate the adiabatic neutralization with $\mathrm{Ca}(\mathrm{OH})_{2}$, which is described in the following reaction:

$$
\mathrm{Ca}(\mathrm{OH})_{2}+\mathrm{H}_{2} \mathrm{SO}_{4} \rightarrow \mathrm{CaSO}_{4}+2 \mathrm{H}_{2} \mathrm{O}
$$


The reaction enthalpy can be estimated from the respective enthalpy of formation of reagents and products and is obtained as the sum of the product values minus the sum of the reactant values as expressed in Equation (23). Therefore, the adiabatic neutralization with $\mathrm{Ca}(\mathrm{OH})_{2}$ corresponds to $(\Delta \mathrm{H})_{\mathrm{r}}=-214.22 \times 10^{3} \mathrm{~kJ} \cdot \mathrm{kmol}^{-1}$. Considering the total amount of $\mathrm{H}_{2} \mathrm{SO}_{4}$, and the total mass of wastewater, the estimated temperature difference $(\Delta \mathrm{t})$ is thus equal to $3.7^{\circ} \mathrm{C}$. As a result, if we consider the heat of neutralization and the heat of dilution of $\mathrm{H}_{2} \mathrm{SO}_{4}$, the value of temperature difference would correspond to $5.33{ }^{\circ} \mathrm{C}$. This value is considered safe for practical applications.

$$
\begin{gathered}
(\Delta \mathrm{H})_{\mathrm{r}}=\sum_{\mathrm{i}=1}^{\mathrm{n}}(\Delta \mathrm{H})_{\mathrm{f}_{\text {products }}^{298 \mathrm{~K}}}^{2 \mathrm{~m}}-\sum_{\mathrm{i}=1}^{\mathrm{m}}(\Delta \mathrm{H})_{\mathrm{f}_{\text {reactants }}^{298 \mathrm{~K}}} \\
(\Delta \mathrm{H})_{\mathrm{r}}\left[\mathrm{kJ} \cdot \mathrm{mol}^{-1}\right]=[-1425.2-2 * 286]-[-968.6-814.378] \\
\mathrm{Q}_{\text {react }}=-214.22 \mathrm{~kJ} \cdot \mathrm{mol}^{-1}=-214.22 \times 10^{3} \mathrm{~kJ} \cdot \mathrm{kmol}^{-1}
\end{gathered}
$$

\subsection{Neutralization Using $\mathrm{MgO}$}

Another possibility is to perform the neutralization step with $\mathrm{MgO}$; in this case, the reaction proceeds according to the reaction expressed in Equation (25), together with the dissolution of $\mathrm{H}_{2} \mathrm{SO}_{4}$ in Equations (26) and (27).

$$
\begin{gathered}
\mathrm{MgO}+\mathrm{H}_{2} \mathrm{SO}_{4} \rightarrow \mathrm{MgSO}_{4}+\mathrm{H}_{2} \mathrm{O} \\
\mathrm{H}_{2} \mathrm{SO}_{4} \rightarrow \mathrm{H}^{+}+\mathrm{HSO}_{4}{ }^{-} \\
\mathrm{HSO}_{4}^{-} \rightarrow \mathrm{H}^{+}+\mathrm{SO}_{4}{ }^{-2}
\end{gathered}
$$

Equation (25) describes the neutralization reaction and double replacement reaction where $\mathrm{H}_{2}{ }^{+}$and $\mathrm{Mg}^{+2}$ trade places to produce the ionic compound $\mathrm{MgSO}_{4}$, and water. The combined reaction enthalpy of all three reactions $\left(\Delta_{\mathrm{H}}\right)$ corresponds to $-233.251 \mathrm{~kJ} \cdot \mathrm{mol}^{-1}$. The energy balance can be calculated following Equation (28), where $\mathrm{n}$ is the molar flow rate of $\mathrm{H}_{2} \mathrm{SO}_{4}\left(\mathrm{~mol} \cdot \mathrm{s}^{-1}\right)$, $\mathrm{m}$ the total amount of the solution(mol), $\mathrm{k}$ the heat transfer coefficient $\left(\mathrm{kJ} /\left(\mathrm{s} \cdot \mathrm{m}^{2} \cdot \mathrm{K}\right)\right), \mathrm{S}$ the surface of the tank $\left(\mathrm{m}^{2}\right), \mathrm{t}_{0}$ the initial temperature $\left({ }^{\circ} \mathrm{C}\right), \mathrm{t}$ the final temperature $\left({ }^{\circ} \mathrm{C}\right), \mathrm{Cp}$ the specific heat capacity of the blend $\mathrm{kJ} \cdot(\mathrm{kmol} \cdot \mathrm{K})^{-1}$, and $\tau$ the time of the reaction (s).

$$
\begin{aligned}
& \Delta_{\mathrm{H}} \cdot \dot{\mathrm{n}}=\mathrm{S} \cdot \mathrm{k}\left(\mathrm{t}-\mathrm{t}_{0}\right)+\mathrm{Cp} \cdot \mathrm{m} \frac{\mathrm{dt}}{\mathrm{d} \tau} \\
& \frac{\Delta_{\mathrm{H}} \cdot \dot{\mathrm{n}}}{\mathrm{Cp} \cdot \mathrm{m}}=\frac{\mathrm{Sk}}{\mathrm{Cp} \cdot \mathrm{m}} \mathrm{t}-\frac{\mathrm{S} \cdot \mathrm{k} \cdot \mathrm{t}_{0}}{\mathrm{Cp} \cdot \mathrm{m}}+\frac{\mathrm{dt}}{\mathrm{d} \tau} \\
& \frac{\left(\Delta_{\mathrm{H}} \cdot \dot{\mathrm{n}}+\mathrm{S} \cdot \mathrm{k} \cdot \mathrm{t}_{0}\right)}{\mathrm{Cp} \cdot \mathrm{m}}=\frac{\mathrm{S} \cdot \mathrm{k}}{\mathrm{Cp} \cdot \mathrm{m}} \mathrm{t}+\frac{\mathrm{dt}}{\mathrm{d} \tau}
\end{aligned}
$$

The previous equation can be also expressed as:

$$
\mathrm{t}=\frac{\mathrm{A}}{\mathrm{B}}-\left(\frac{\mathrm{A}}{\mathrm{B}}-\mathrm{t}_{0}\right) \mathrm{e}^{-\mathrm{B} \tau}
$$

where $\mathrm{A}\left[\mathrm{K} \cdot \mathrm{s}^{-1}\right]=\left(\Delta_{\mathrm{H}} \cdot \dot{\mathrm{n}}+\mathrm{S} \cdot \mathrm{k} \cdot \mathrm{t}_{0}\right) /(\mathrm{Cp} \cdot \mathrm{m})$, and $\mathrm{B}\left[\mathrm{s}^{-1}\right]=\mathrm{S} \cdot \mathrm{k} /(\mathrm{Cp} \cdot \mathrm{m})$. In practice, it is common to find the tank reactors are located outside the factory. Therefore, it is important to know how the surrounding temperature affects the temperature of the reactor. Numerical simulation of previous equation is presented on Figure 2 and is performed with the following parameters $\Delta_{\mathrm{H}}: 233.251 \mathrm{~kJ} \cdot \mathrm{mol}^{-1}, \dot{\mathrm{n}}: 8.5 \times 10^{-4} \mathrm{kmol} \cdot \mathrm{s}^{-1}$, which represents a flow of $5 \mathrm{~kg} \mathrm{H}_{2} \mathrm{SO}_{4} \cdot \mathrm{min}^{-1}, \mathrm{~S}: 4.7 \mathrm{~m}^{2}, \mathrm{~m}: 46.16 \mathrm{kmol}, \mathrm{k}: 0.01 \mathrm{~kJ} \cdot\left(\mathrm{s} \cdot \mathrm{m}^{2} \cdot \mathrm{K}\right)^{-1}$, $\mathrm{t}_{0}: 10^{\circ} \mathrm{C}, \mathrm{Cp}: 134.5 \mathrm{~kJ} \cdot(\mathrm{kmol} \cdot \mathrm{K})^{-1}$, which were obtained considering a $20 \%$ solution of $\mathrm{MgSO}_{4}$. The surrounding temperature of $10^{\circ} \mathrm{C}$ simulates the case of performing the 
experiment during winter time, whereas hotter temperatures of about $30{ }^{\circ} \mathrm{C}$ represent average summer temperatures.

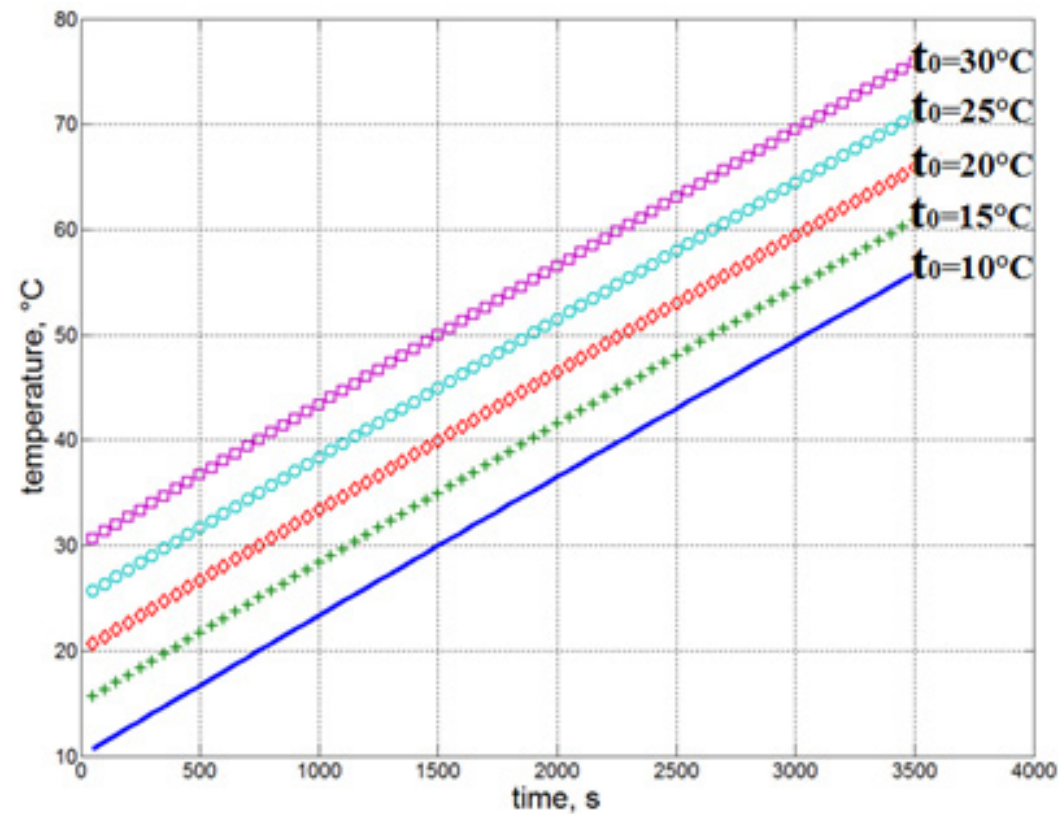

Figure 2. Variation of the reaction temperature with surrounding temperature $\left(10{ }^{\circ} \mathrm{C}<\mathrm{t}_{0}<30^{\circ} \mathrm{C}\right)$ during the neutralization step using $\mathrm{MgO}$.

The reaction of urea in sulfuric acid is irreversible. It takes place in the liquid phase and the volume of carbon dioxide gas only affects the reaction at higher pressures. In order to know if the variation in liquid volume in the tank due to addition of $\mathrm{H}_{2} \mathrm{SO}_{4}$ would significantly affect the increment in temperature, we realized an energy balance considering the input flow of a solution, as presented in the following equation:

$$
\mathrm{N}=\frac{\mathrm{Cp} \cdot \mathrm{t} \cdot \mathrm{N}}{\Delta \mathrm{H}_{\mathrm{k}}}+\mathrm{Cp}\left(\mathrm{m}_{\mathrm{o}}+\frac{\mathrm{N} \cdot \tau}{\Delta \mathrm{H}_{\mathrm{k}}}\right) \frac{\mathrm{dt}}{\mathrm{d} \tau}+\mathrm{k} \cdot \mathrm{S}\left(\mathrm{t}-\mathrm{t}_{0}\right)
$$

where $\mathrm{N}$ is the power input of energy $(\mathrm{W}), \mathrm{Cp}$ the specific heat of the solution, $\mathrm{t}$ the temperature of the reaction, $\Delta \mathrm{H}_{\mathrm{k}}$ the enthalpy of steam condensation, $\mathrm{m}_{\mathrm{o}}$ the initial mass of water in the tank, $\mathrm{k}$ the heat transfer coefficient, $\mathrm{S}$ the surface area, and $\mathrm{t}_{0}$ the initial temperature. The solution of the previous equation leads to the estimation of temperature $(t)$ as expressed in the following equation:

$$
t=\frac{\frac{\Delta H_{k}}{C p}+\frac{k \cdot S \cdot \Delta H_{k} \cdot t_{0}}{C p \cdot N}}{\frac{k \cdot S \cdot \Delta H_{k}}{C p \cdot N}+1}-\left(\frac{\frac{\Delta H_{k}}{C p}+\frac{k \cdot S \cdot \Delta H_{k} \cdot t_{0}}{C p \cdot N}}{-\frac{k \cdot S \cdot \Delta H_{k}}{C p \cdot N}-1}+t_{0}\right)\left(\frac{\frac{m_{0} \cdot \Delta H_{k}}{N}+\tau}{\frac{m_{0} \cdot \Delta H_{k}}{N}}\right)^{-\frac{k \cdot S \cdot \Delta H_{k}}{C p \cdot N}-1}
$$

Figure 3 presents a comparison of the temperature variation with and without consideration of the variation of mass input flow. It can be seen that the temperature is slightly lower when considering the case of continuous addition of a solution. After one hour, the temperature would be $65{ }^{\circ} \mathrm{C}$ instead of $71^{\circ} \mathrm{C}$, representing an error of $8.5 \%$.

The influence of rate addition of $\mathrm{H}_{2} \mathrm{SO}_{4}$ on time and temperature was also studied for a range of 0 to 10 and is presented in Figure 4. This represents how fast the sulfuric acid is added and ultimately also affects the time the reaction will finish. The faster the $\mathrm{H}_{2} \mathrm{SO}_{4}$ is added, the sooner the reaction will take place. 

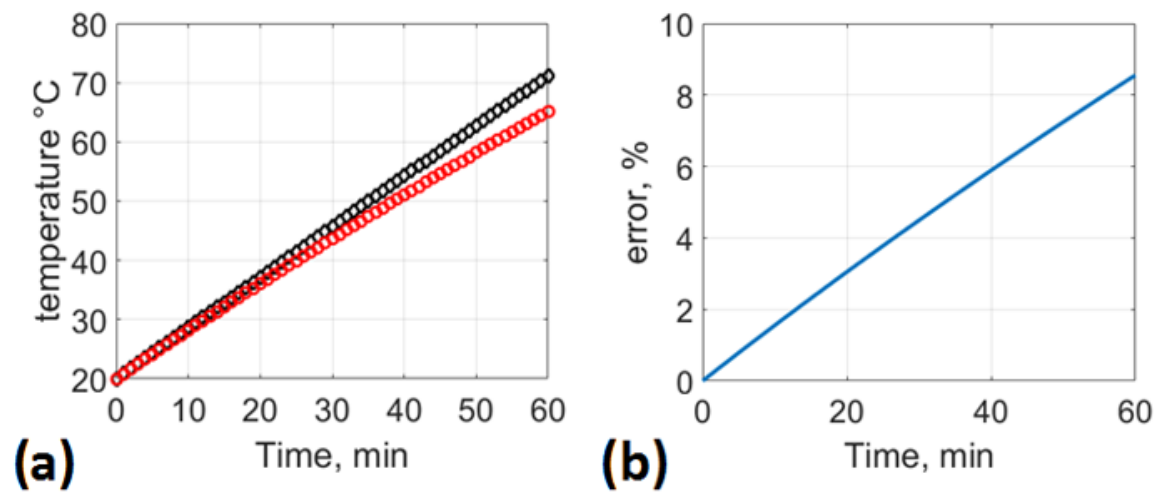

Figure 3. (a) Comparison of the reaction blend temperature considering the influence of input flow addition $(\mathrm{O})$ and constant volume $(\diamond)$, (b) error variation presented as percentage, $0 \leq \tau \leq 60 \mathrm{~min}$.
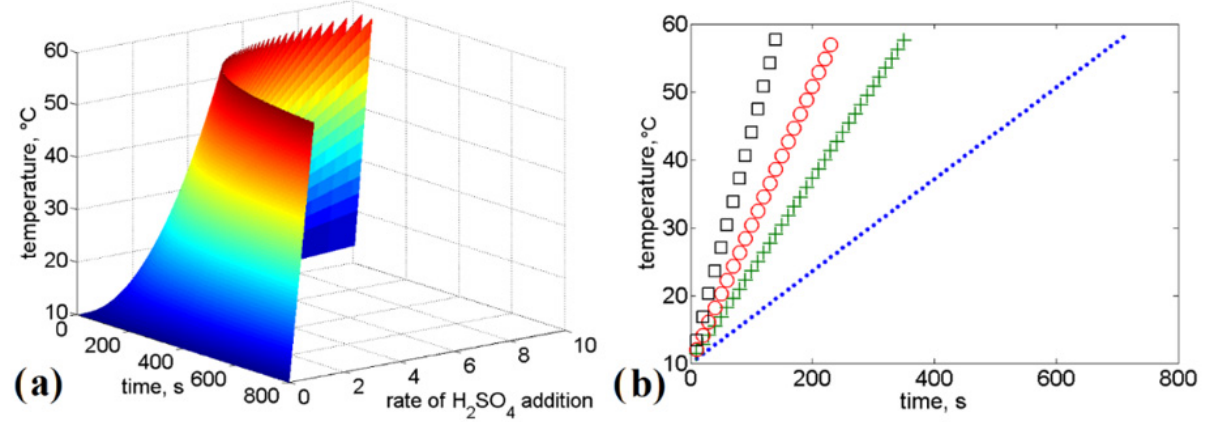

Figure 4. (a) Influence of rate of $\mathrm{H}_{2} \mathrm{SO}_{4}$ addition on temperature and reaction time; (b) selected values of addition rate: $(\square)$ rate: $5 x\left(25 \mathrm{~kg} \cdot \mathrm{min}^{-1}\right)$; (O) rate: $3 x\left(15 \mathrm{~kg} \cdot \mathrm{min}^{-1}\right)$; (+) rate: $2 x\left(10 \mathrm{~kg} \cdot \mathrm{min}^{-1}\right)$; (•) rate: $1 \mathrm{x}\left(5 \mathrm{~kg} \cdot \mathrm{min}^{-1}\right) .0 \leq \tau \leq 800 \mathrm{~s}$.

As an example, if $x$ represents a rate of addition equal to $5 \mathrm{~kg} \mathrm{~min}^{-1}$, when the addition of $\mathrm{H}_{2} \mathrm{SO}_{4}$ is $1 \mathrm{x}\left(5 \mathrm{~kg} \cdot \mathrm{min}^{-1}\right)$, using $60 \mathrm{~kg}$ of $\mathrm{H}_{2} \mathrm{SO}_{4}(0.61 \mathrm{kmol})$ since $\dot{\mathrm{n}}=8.5 \times 10^{-4} \mathrm{kmol} \cdot \mathrm{s}^{-1}$, the amount of time required corresponds to $0.61 \mathrm{kmol} / 8.5 \times 10^{-4} \mathrm{kmol} \cdot \mathrm{s}^{-1}=717.6 \mathrm{~s}=$ $11.96 \mathrm{~min}$. The required time is substituted in Equation (31), where constants A and B are determined as follows:

$$
\begin{gathered}
\mathrm{A}=\frac{\left(233,353 \times \mathrm{mol} \cdot 510^{-0} \mathrm{kmol} \cdot \mathrm{s}^{-\mathrm{m}}+4.7 \mathrm{~m}^{2} \times 4.7 \mathrm{~kJ} \cdot\left(\mathrm{s} \cdot \mathrm{m}^{2}\right)^{-1} \times \mathrm{J} 7\right)}{2894.4 \mathrm{~kJ} \cdot \mathrm{K}^{-\mathrm{J}}}=0.0687 \mathrm{~s}^{-1} \mathrm{~K} \\
\mathrm{~B}=\frac{4.7 \mathrm{~m}^{2} \times 0.01 \mathrm{~kJ} \cdot\left(\mathrm{s} \cdot \mathrm{m}^{2} \cdot \mathrm{K}\right)^{-1}}{134 \mathrm{~kJ} \cdot(\mathrm{kmol} \cdot \mathrm{K})^{-1} \cdot 21.6 \mathrm{kmol}}=1.6 \times 10^{-5} \mathrm{~s}^{-1}
\end{gathered}
$$

After substitution of $\mathrm{A}$ and $\mathrm{B}$ in Equation (31), with a surrounding temperature of $10{ }^{\circ} \mathrm{C}$, a temperature of $58.9^{\circ} \mathrm{C}$ is obtained. The previous example was performed experimentally on the premises of a milk farm. The measured temperature oscillated between 58 and $61{ }^{\circ} \mathrm{C}$ during the first $30 \mathrm{~min}$.

\subsection{Stabilization of Urea with Phosphoric Acid}

In an additional attempt to model the reaction of urea with acids, we took into consideration the reaction of urea with phosphoric acid in which ammonium dihydrogen phosphate is produced. The advantage of performing urea stabilization with phosphoric acid is the generation of nitrogenous and phosphorous fertilizers. This also allows the possibility to formulate mixtures of fertilizers containing $\mathrm{N}, \mathrm{P}$, urea, and elemental sulfur. Phosphorus is another macronutrient required for plant growth $\left(>2000 \mathrm{mg} \cdot \mathrm{kg}^{-1}\right)$. Besides its use as fertilizer, ammonium dihydrogen phosphate also finds application during the fermentation of wine grapes and for the production of wine vinegar using apple cider to 
complement nutritional requirements for acetic acid bacteria that produce vinegar with up to $15 \%$ acetic acid [26]. We consider that the following reaction takes place:

$$
\mathrm{CH}_{4} \mathrm{~N}_{2} \mathrm{O}+2 \mathrm{H}_{3} \mathrm{PO}_{4}+\mathrm{H}_{2} \mathrm{O} \rightarrow 2\left(\mathrm{NH}_{4}\right) \mathrm{H}_{2} \mathrm{PO}_{4}+\mathrm{CO}_{2}
$$

The functional relation between rate and concentration of urea $\left(\mathrm{C}_{\mathrm{CH}_{4} \mathrm{~N}_{2} \mathrm{O}}\right)$ and phosphoric acid $\left(\mathrm{C}_{\mathrm{H}_{3} \mathrm{PO}_{4}}\right)$ can be determined by the model represented by the overall third order expression (Equation (37)):

$$
-\frac{\mathrm{dC}_{\mathrm{CH}_{4} \mathrm{~N}_{2} \mathrm{O}}}{\mathrm{d} \tau}=\mathrm{k} \cdot\left[\mathrm{C}_{\mathrm{CH}_{4} \mathrm{~N}_{2} \mathrm{O}}\right]\left[\mathrm{C}_{\mathrm{H}_{3} \mathrm{PO}_{4}}\right]^{2}
$$

where $\mathrm{C}_{\mathrm{CH}_{4} \mathrm{~N}_{2} \mathrm{O}}=\mathrm{C}_{\left(\mathrm{CH}_{4} \mathrm{~N}_{2} \mathrm{O}\right)_{0}}-\mathrm{X}_{\mathrm{CH}_{4} \mathrm{~N}_{2} \mathrm{O}}$, and $\mathrm{C}_{\mathrm{H}_{3} \mathrm{PO}_{4}}=\left(\mathrm{C}_{\left(\mathrm{H}_{3} \mathrm{PO}_{4}\right)_{0}}-\mathrm{X}_{\mathrm{H}_{3} \mathrm{PO}_{4}}\right), \mathrm{C}_{\left(\mathrm{CH}_{4} \mathrm{~N}_{2} \mathrm{O}\right)_{0}}$ and $\mathrm{C}_{\left(\mathrm{H}_{3} \mathrm{PO}_{4}\right)_{0}}$ are the initial concentration of urea and phosphoric acid while $\mathrm{X}_{\mathrm{CH}_{4} \mathrm{~N}_{2} \mathrm{O} \text { and }}$

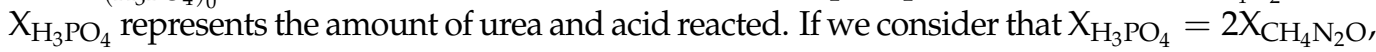
we can rewrite Equation (37) as follows:

$$
\frac{\mathrm{d} \mathrm{X}_{\mathrm{CH}_{4} \mathrm{~N}_{2} \mathrm{O}}}{\mathrm{d} \tau}=\mathrm{k} \cdot\left(\mathrm{C}_{\left(\mathrm{CH}_{4} \mathrm{~N}_{2} \mathrm{O}\right)_{0}} \mathrm{X}_{\mathrm{CH}_{4} \mathrm{~N}_{2} \mathrm{O}}\right)\left(\mathrm{C}_{\left(\mathrm{H}_{3} \mathrm{PO}_{4}\right)_{0}}-2 \mathrm{X}_{\mathrm{CH}_{4} \mathrm{~N}_{2} \mathrm{O}}\right)^{2}
$$

The analytical integration yields:

$\frac{1}{\left(\mathrm{C}_{\left(\mathrm{H}_{3} \mathrm{PO}_{4}\right)_{0}}-2 \mathrm{C}_{\left(\mathrm{CH}_{4} \mathrm{~N}_{2} \mathrm{O}\right)_{0}}\right)^{2}}\left[\ln \frac{\left|\mathrm{C}_{\left(\mathrm{CH}_{4} \mathrm{~N}_{2} \mathrm{O}\right)_{0}}\left(\mathrm{C}_{\left(\mathrm{H}_{3} \mathrm{PO}_{4}\right)_{0}}-2 \mathrm{X}_{\mathrm{CH}_{4} \mathrm{~N}_{2} \mathrm{O}}\right)\right|}{\left|\mathrm{C}_{\left(\mathrm{H}_{3} \mathrm{PO}_{4}\right)_{0}}\left(\mathrm{C}_{\left(\mathrm{CH}_{4} \mathrm{~N}_{2} \mathrm{O}\right)_{0}}-\mathrm{X}_{\mathrm{CH}_{4} \mathrm{~N}_{2} \mathrm{O}}\right)\right|}\right]-\frac{1}{\mathrm{C}_{\left(\mathrm{H}_{3} \mathrm{PO}_{4}\right)_{0}}-2 \mathrm{C}_{\left(\mathrm{CH}_{4} \mathrm{~N}_{2} \mathrm{O}_{0}\right.}}\left[\frac{1}{\left(\mathrm{C}_{\left(\mathrm{H}_{3} \mathrm{PO}_{4}\right)_{0}}-2 \mathrm{X}_{\left.\mathrm{CH}_{4} \mathrm{~N}_{2} \mathrm{O}\right)}\right.}-\frac{1}{\left(\mathrm{C}_{\left(\mathrm{H}_{3} \mathrm{PO}_{4}\right)_{0}}\right)}\right]=\mathrm{k} \tau$

The solution to this equation was derived using the implicit method and numerical approximation to the solution by developing an algorithm in MATLAB. The approach solution is to give several values to $\mathrm{X}_{\mathrm{CH}_{4} \mathrm{~N}_{2} \mathrm{O}}$ until the value obtained on the left-hand side corresponds to the value on the right-hand side of the equation. The solution is presented in the following plots. We present three study cases. The first two cases consider the use of initial concentration of phosphoric acid which are 2.5 and 1.5 times higher than the initial concentration of urea, whereas the third case assumes equal concentration of urea and phosphoric acid. The corresponding conversion profile is shown in Figure 5. There is a sharp increase in conversion at early times and at higher $\mathrm{H}_{3} \mathrm{PO}_{4}$ ratios. When the amount of $\mathrm{H}_{3} \mathrm{PO}_{4}$ is 1.5 times higher, there is no full urea conversion. This shows that complete conversion of urea can be achieved using concentrations of $\mathrm{H}_{3} \mathrm{PO}_{4}$ which are at least 2.5 times higher than the initial concentration of urea. However, this is achieved at longer times $(>30 \mathrm{~h}$ ). Therefore, fast conversion can be obtained with higher concentrations of the acid. To exemplify this, numerical analysis was performed considering concentrations which are 5, 8, and 10 times higher than the initial concentration of urea. This is represented in Figure 5b).

A quantitative method for determination of $\mathrm{H}_{3} \mathrm{PO}_{4}$ and urea was developed using High Performance Liquid Chromatography. Experiments were realized between phosphoric acid and urea in a molar ratio using $0.66 \mathrm{~mol} \mathrm{H}_{3} \mathrm{PO}_{4} / \mathrm{mol}$ urea, $1.22 \mathrm{~mol} \mathrm{H}_{3} \mathrm{PO}_{4} / \mathrm{mol}$ urea and $1.5 \mathrm{~mol} \mathrm{H}_{3} \mathrm{PO}_{4} / \mathrm{mol}$ urea. A method was developed for reliable separation and identification of both compounds. The main challenge was that both compounds eluted at a similar retention time, which compliated their quantification. We used a Shim-Pack VP-ODS $(250 \mathrm{~mm} \times 4.6 \mathrm{~mm})$ column. After several approaches, the best method that separated both compounds was using a temperature of $30{ }^{\circ} \mathrm{C}$ in isocratic mode with a mixture of Acetonitrile: $\mathrm{H}_{2} \mathrm{O}(5: 95 \mathrm{v} / \mathrm{v})$ as mobile phase, with a flow of $0.4 \mathrm{~mL} \cdot \mathrm{min}^{-1}$ using a UV and RI detector. A calibration curve was prepared between $0.25 \%$ and $2 \%$ for both detectors. Urea (in solid form) and $\mathrm{H}_{3} \mathrm{PO}_{4}$ were of analytical grade and obtained from PENTA s.r.o. company. Analytical measurements using HPLC showed decrement in $\mathrm{H}_{3} \mathrm{PO}_{4}$ concentration but not in urea concentration, as presented in Figure 6. This indicates that the value of rate constant for the reaction condition is of lower magnitude $\left(<1 \times 10^{-5}\right)$. 

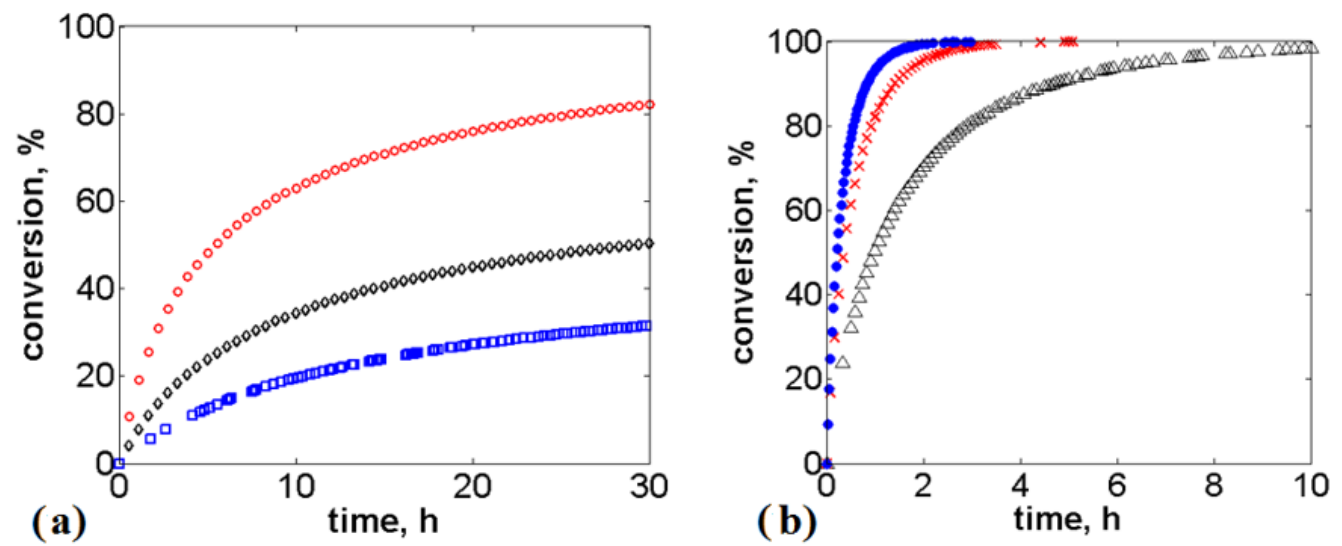

Figure 5. (a) Plot of amount of urea reacted vs. time considering values of phosphoric acid concentration between 1 and 2.5. (O) $\mathrm{C}_{\left(\mathrm{H}_{3} \mathrm{PO}_{4}\right)_{0}}=2.5, \mathrm{C}_{\left(\mathrm{CH}_{4} \mathrm{~N}_{2} \mathrm{O}\right)_{0}}=1, \mathrm{k}=1 \times 10^{-5}$; $(\diamond) \mathrm{C}_{\left(\mathrm{H}_{3} \mathrm{PO}_{4}\right)_{0}}=1.5, \mathrm{C}_{\left(\mathrm{CH}_{4} \mathrm{~N}_{2} \mathrm{O}\right)_{0}}=1, \mathrm{k}=1 \times 10^{-5} ;(\square) \mathrm{C}_{\left(\mathrm{H}_{3} \mathrm{PO}_{4}\right)_{0}}=1, \mathrm{C}_{\left(\mathrm{CH}_{4} \mathrm{~N}_{2} \mathrm{O}\right)_{0}}=1, \mathrm{k}=1 \times 10^{-5}$. (b) Plot of $\mathrm{X}_{\mathrm{CH}_{4} \mathrm{~N}_{2} \mathrm{O}}$ vs. time considering values of phosphoric acid concentration between 5 and 10 . ( $\Delta) \mathrm{C}_{\left(\mathrm{H}_{3} \mathrm{PO}_{4}\right)_{0}}=5, \mathrm{C}_{\left(\mathrm{CH}_{4} \mathrm{~N}_{2} \mathrm{O}\right)_{0}}=1, \mathrm{k}=1 \times 10^{-5} ;(\times) \mathrm{C}_{\left(\mathrm{H}_{3} \mathrm{PO}_{4}\right)_{0}}=8, \mathrm{C}_{\left(\mathrm{CH}_{4} \mathrm{~N}_{2} \mathrm{O}\right)_{0}}=1, \mathrm{k}=1 \times 10^{-5}$; (•) $\mathrm{C}_{\left(\mathrm{H}_{3} \mathrm{PO}_{4}\right)_{0}}=10, \mathrm{C}_{\left(\mathrm{CH}_{4} \mathrm{~N}_{2} \mathrm{O}\right)_{0}}=1, \mathrm{k}=1 \times 10^{-5}$.
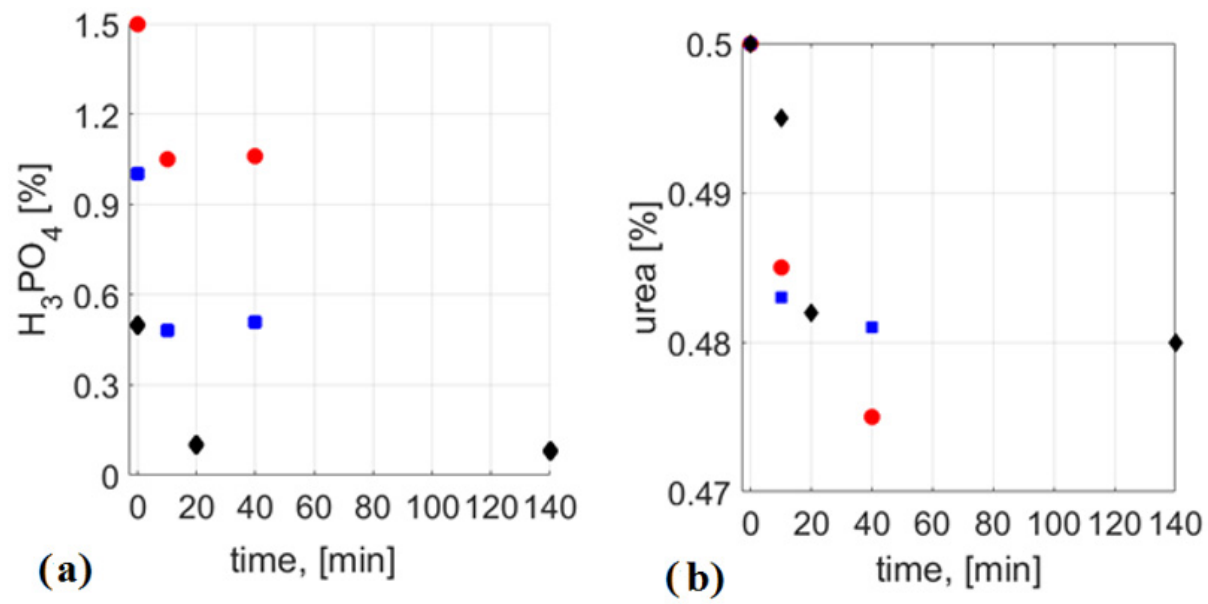

Figure 6. Variation of $\mathrm{H}_{3} \mathrm{PO}_{4}(\mathbf{a})$ and urea concentration (b) in experiments performed using a molar ratio of $0.66 \mathrm{~mol} \mathrm{H}_{3} \mathrm{PO}_{4} / \mathrm{mol}$ urea $(\diamond), 1.22 \mathrm{~mol} \mathrm{H}_{3} \mathrm{PO}_{4} / \mathrm{mol}$ urea $(\square), 1.5 \mathrm{~mol} \mathrm{H}_{3} \mathrm{PO}_{4} / \mathrm{mol}$ urea $(\bullet)$.

\subsection{Sedimentation Experiments}

Another series of experiments to visualize the potential application consisted in the sedimentation of wastewater from a dairy factory which produces milk by breeding 1500 dairy cows. This farm produces up to $50 \mathrm{~m}^{3}$ of wastewater per day, and the average value of COD is $6000 \mathrm{mg} \cdot \mathrm{L}^{-1}$. The main task is to design a settling system that would allow the desired separation of the solid phase so that the separated (upper) layer decreases in chemical oxygen demand (COD). After calculation of the dimensionless criteria of Lyashenko (Ly) and Reynolds (Re), we found parameters for estimating the settling rate. To perform the experiment, $100 \mathrm{~mL}$ of rinsing water from a dairy factory with $\mathrm{pH}$ 7, dry matter content of $0.9 \%$, and COD value of $2816 \mathrm{mg} \cdot \mathrm{L}^{-1}$ were mixed with $2 \mathrm{~g} \mathrm{MgO}$ for $60 \mathrm{~min}$ and then poured into a $100 \mathrm{~mL}$ graduated measuring cylinder ( $26 \mathrm{~mm}$ diameter) to reach a $\mathrm{pH}$ of 11 , and the rate of sedimentation was monitored at different times. The solution was then neutralized with $0.52 \mathrm{~g}$ of $\mathrm{H}_{3} \mathrm{PO}_{4}$ topH 7 and the rate of sedimentation of the clarified liquid was measured again. The average rate of settlement using $\mathrm{MgO}$ was $2.41 \times 10^{-5} \mathrm{~m} \cdot \mathrm{s}^{-1}$ and $7.3 \times 10^{-5} \mathrm{~m} \cdot \mathrm{s}^{-1}$ using $\mathrm{H}_{3} \mathrm{PO}_{4}$. The final amount of dry matter of the clarified layer was $0.7 \%$ and $2112 \mathrm{mg} \cdot \mathrm{L}^{-1}$ of COD. The sediment settling rate was significantly higher after neutralization. In a second settlement experiment, $100 \mathrm{~mL}$ of rinsing water was stirred with $1 \mathrm{~g} \mathrm{Ca}(\mathrm{OH})_{2}$ for $15 \mathrm{~min}(\mathrm{pH} 11)$ and then neutralized with 
$2 \mathrm{~g}$ of $\mathrm{H}_{3} \mathrm{PO}_{4}$. Sediment deposition in the measuring cylinder was monitored. Dry matter of the upper layer after neutralization was $1.0 \%$, the COD value of the upper layer was $1440 \mathrm{mg} \cdot \mathrm{L}^{-1}$, and the nitrogen content in the upper layer was $0.055 \%$. The settling rate of the experiments performed is presented in Figure 7. These experiments showed the potential of using a sedimentation system (i.e., $\mathrm{Ca}(\mathrm{OH})_{2}-\mathrm{H}_{2} \mathrm{SO}_{4}$ ) to reduce up to $50 \%$ of the initial COD consumption. This has the additional benefit of contributing to a potential reuse of water, particularly in operations such as floor cleaning and sanitization.

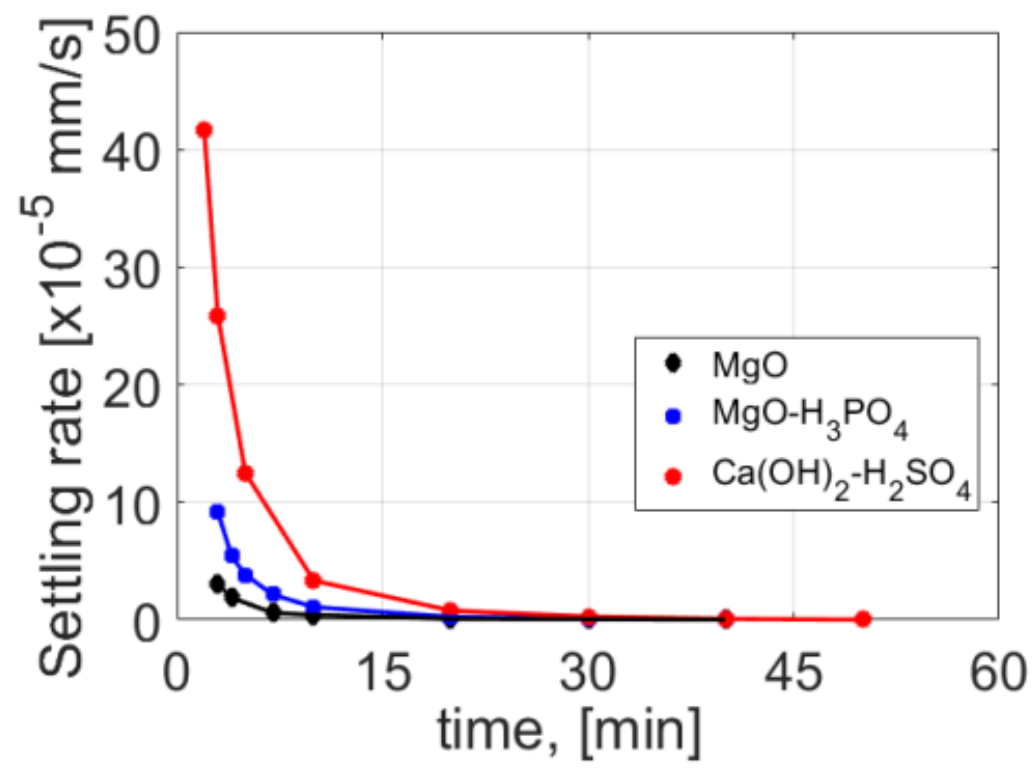

Figure 7. Average settling rate of suspended particles after sedimentation using $\mathrm{MgO}, \mathrm{MgO}-\mathrm{H}_{3} \mathrm{PO}_{4}$, and $\mathrm{Ca}(\mathrm{OH})_{2}-\mathrm{H}_{2} \mathrm{SO}_{4}$.

\section{Discussion}

One of the main problems present in agricultural production is the disposal of organic waste. Wastewater contains an average of 5\% dry matter, which is in the form of fine particles' dispersion. Dry matter is produced by excrement and has a major share in the high COD value, which has to be reduced. Very often, the treatment is performed on the premises of the company; however, problems can arise when the capacity of the treatment plant is at critical levels, particularly during periods of drought and clean water deficit, which are factors that present a real threat to its efficiency. An alternative could be the construction of an upstream separation plant, where streams with higher chemical demand of oxygen could be reduced to the standard required values through coagulation and sedimentation. As a result, the liquid phase with reduced COD values could be partially recycled and purified at the treatment plant. Recent periods of severe drought have caused a sharp drop in groundwater levels and thus of its reserves. This has been a problem for farms which frequently rely on using water sources coming from their own wells, thus forcing them to use water from public sources and increasing operating costs. The reduction in the COD level allows the company to avoid operating at critical limits of its capacity, and decreases the load on the wastewater treatment plant and consumption of incoming clean water. The coagulated solid phase can be drained and used as a valuable organic nitrogen fertilizer.

Several sources of nitrogenous and phosphorous fertilizer are used in agriculture including ammonia, urea, ammonium nitrate, phosphonitrate, ammonium sulfate, anhydrous ammonia, potassium nitrate, di-ammonium phosphate, and monoammonium phosphate. They differ not only in the content of $\mathrm{N}$ or $\mathrm{K}$, but also in the efficiency, as not all is used and assimilated equally by the plant. Ammonia, for example, has a $\mathrm{N}$ content of $82 \%$ but because it is in gas phase, only between $30 \%$ and $50 \%$ is approximately absorbed by the plant as the rest is lost through volatilization. By comparison, ammonium 
sulfate has a $\mathrm{N}$ content of $21 \%$ but has an efficiency between $70 \%$ and $85 \%$. Efficiency values represent the $\mathrm{kg}$ of biomass produced per $\mathrm{kg}$ of nutrient applied. These values can be improved by means of fractional fertilization as fewer amounts of nutrients are lost through washing or soil drainage. Another factor that should be taken into account is the cation exchange capacity of the soil. Soil colloid has a negative charge; as a result, it has affinity towards cations and repels anions according to the number of positive charges of the ion. In the case of heavy rain, nitrates tend to be leached from the soil or drained in the case of soil saturation leading to loss of nitrogen, which is not the case when nitrogen is incorporated in the fertilizer as ammonium nitrate, di-ammonium phosphate, or monoammonium phosphate. Accordingly, it is important to know that there is no unique fertilizer that will solely improve the efficiency of a crop. Several factors, such as season, daily temperatures, soil properties, humidity, type of crop, soil salinity, pests, and diseases will determine the efficiency. Running tests in a control zone and through several rows placed on different parts of the field for assessing the crop response to different fertilizer rates and nutrient combinations allows farmers to conduct research on their own soil and fields for that particular season of the year and conditions.

Another factor that influences the fertilizer efficiency is the plant growth stage at which it is applied. It is important to consider the use of fertilizer from the sprout phase through the vegetative phase and before the flowering to have better assimilation of nutrients. This implies the use of fractional fertilization adding different quantities of nutrients according to the physicochemical characterization of the soil $(\mathrm{pH}$, salinity and nutrients concentration, microbial diversity in the soil etc.) and environmental parameters (temperature, humidity, etc.).

The stabilization of urea from wastewater also has the added benefit of contributing significantly to the reduction in the value of COD. It also prevents the growth of microorganisms due to biofilm and planktonic growth [27]. Additionally, the implementation of this type of technologies would reduce the consumption of pure water by recycling the separated liquid. After acid stabilization of urea and further neutralization with alkali, the solid phase has the potential to be used as a valuable nitrogen fertilizer. Part of the separated liquid with a low COD value of about $60 \%$ can be recycled and used as rinsing water in the washing of floors. This will reduce the load on the wastewater treatment plant and the consumption of incoming clean water, and help to solve problems related to dry seasons.

One of the main nutrients needed for the nutrition of cultivated plants is nitrogen, which is supplied to the soil in the form of organic compounds or as inorganic soluble nitrogen salts. It is important to keep in mind that inorganic nitrogen fertilizer supplies the cultivated plant with the necessary nitrogen, but can also negatively affect the soil structure by reducing its ability to bind the necessary nutrients. For this reason, there has been a recent increase in interest in organic nitrogen fertilizers. However, natural sources of nitrogen organic fertilizers are limited, and for this reason an effort to obtain new sources for organic nitrogen fertilizers is recommended. Additionally, this type of organic fertilizer has the potential to be applied as biostimulants, and to increase the plant resistance to immunity to a wide range of harmful pathogens, and also as biological insecticides. Successful attempts were previously reported by our research group, using an organo-nitrogenous fertilizer (enzymatic hydrolysate) in lettuce plants. Considerable differences were found in the yields and nitrate concentration in comparison to a control crop (unfertilized soil) and an available commercial fertilizer (blend of ammonium nitrate and urea in a 1:1 ratio based on nitrogen content). This had a positive effect on the growth and development of the tested lettuce plants with a considerable higher value as a foodstuff, taking into account the low nitrates content obtained in the plant treated with the enzymatic hydrolysate [28]. 


\section{Conclusions}

The proposed reaction system has the potential to be used in places where urine is disposed in the wastewater. The farm industry is one example, in the special case that the liquid residues originated from the sanitization and washing of floors that contained urea. The reactions studied contribute to the production of ammonium sulfate and ammonium dihydrogen phosphate. The proposed reaction of urea with sulfuric acid and phosphoric acid also yields multiple compounds, such as ammonium hydrogen sulfate, amidosulfonic acid, or urea phosphate. We focused our analysis on the modeling of ammonium sulfate and ammonium dihydrogen phosphate due to their importance as fertilizers. However, the presence of other multiple compounds does not cause nitrogen losses, which is the key parameter for application in agriculture. Those compounds can be used to prepare a balanced solution containing $\mathrm{N}, \mathrm{S}$, and $\mathrm{K}$, and complement fertilizer mixtures tailored to the characteristics of the particular soil and crop to provide the missing nutritional elements, and also based on additional characteristics such as $\mathrm{pH}$, organic matter, and texture. Proper understanding and quantification of how the nutrients are diffused and transformed in the soil, including by the action of enzymes and microorganisms, i.e., mineralization, reduction, and oxidation, is essential for a sustainable agricultural management.

Enrichment of the resulting fertilizer with phosphorus could be also approached by performing firstly alkaline hydrolysis of the feedstock, followed by adjust of the $\mathrm{pH}$ to a level suitable for the use of proteolytic enzymes by neutralization with phosphoric or nitric acid. At the end of both phases of the hydrolysis, the $\mathrm{pH}$ could be adjusted to a value close to 7; with this combination, the resulting hydrolysate would also be enriched in potassium. Additionally, further derived products based on phosphorus in the form of polyphosphate can be also considered to analyze the most suitable form in terms of applicability to the plant.

In the present study, we analyzed urea stabilization in acid media. Particular attention was given to the use of sulfuric acid and phosphoric acid. The kinetic rate law is a function of the intensive properties of the reagents, namely, temperature, pressure, and concentration. As the reaction rate is strongly dependent on the concentration of reacting species, it is common to express the reaction rate as a function of conversion. Numerical analysis was performed to evaluate the influence of the rate of addition of reagents, rate constants, and time on urea conversion. It was observed that the rate of urea conversion was affected by the rate of acid addition. The required time for urea conversion was reduced when the initial concentration of acid was several times higher than the initial concentration of urea.

An additional benefit of urea stabilization by acid media, followed by the neutralization step, could be the significant increase in the economic efficiency of the current production in the farm industry, from the ecological and economic point of view, due to the generation of a fertilizer containing nitrogen that can be used on the same farm, and the potential reuse of the treated wastewater containing urea.

Author Contributions: All listed authors contributed significantly to the present manuscript, in the performance of experiments, analysis of results, discussion and preparation of the article in every draft, and version, which consequently led to the final version approved by all authors. Conceptualization was performed by J.C.B.-P.; methodology by K.K.; software by J.C.B.-P.; validation by J.C.B.-P. and K.K.; writing-original draft preparation by J.C.B.-P.; writing-review and editing by J.C.B.-P. and K.K.; supervision by K.K. All authors have read and agreed to the published version of the manuscript.

Funding: Funding provided by the agricultural cooperative of owners ZDV Frystak (Zemědělské družstvo vlastníků Fryšták) is gratefully acknowledged. Authors appreciate their financial support to perform the research and for allowing us to publish the results. We thank Precheza Company Prerov for the free supply of sulfuric acid for operational experiments. Additional funding was provided by the Ministry of Industry and Trade of the Czech Republic. Operational Programme Enterprise and Innovation for Competitiveness (OP EIC). Project number: CZ.01.1.02/0.0/0.0/18_215/0020606. 
Institutional Review Board Statement: Not applicable.

Informed Consent Statement: Not applicable.

Data Availability Statement: The main results of the mathematical modeling are presented in forms of figures.

Acknowledgments: Funding provided by the agricultural cooperative of owners ZDV Frystak (Zemědělské družstvo vlastníků Fryšták) is gratefully acknowledged. Authors appreciate their financial support to perform the research and for allowing us to publish the results. We thank Precheza Company Prerov for the free supply of sulfuric acid for operational experiments. Funding was additionally provided by the Ministry of Industry and Trade of the Czech Republic. Operational Programme Enterprise and Innovation for Competitiveness (OP EIC). Project number: CZ.01.1.02/0.0/0.0/18_215/0020606.

Conflicts of Interest: The authors declare no conflict of interest. The funders had no role in the design of the study; in the collection, analyses, or interpretation of data; in the writing of the manuscript, or in the decision to publish the results.

\section{References}

1. Bean, E.S.; Atkinson, D.E. Regulation of the Rate of Urea Synthesis in Liver by Extracellular pH. J. Biol. Chem. 1984, 259, 1552-1559. [CrossRef]

2. Bristow, A.W.; Whitehead, D.C.; Cockburn, J.E. Nitrogenous constituents in the urine of cattle, sheep and goats. J. Sci. Food Agric. 1992, 59, 387-394. [CrossRef]

3. Gratzfeld, D.; Heitkämper, J.; Debailleul, J.; Olzmann, M. On the influence of water on urea condensation reactions: A theoretical study. Z. Phys. Chem. 2020, 234, 1311-1327. [CrossRef]

4. Mikkelsen, R. Biuret in urea fertilizer. Fertil. Res. 1990, 26, 311-318. [CrossRef]

5. Seifan, M.; Sarabadani, Z.; Berenjian, A. Development of an Innovative Urease-Aided Self-Healing Dental Composite. Catalysts 2020, 10, 84. [CrossRef]

6. Sigurdarson, J.J.; Svane, S.; Karring, H. The molecular processes of urea hydrolysis in relation to ammonia emissions from agriculture. Rev. Environ. Sci. Biotechnol. 2018, 17, 241-258. [CrossRef]

7. Randall, D.G.; Krähenbühl, M.; Köpping, I.; Larsen, T.A.; Udert, K.M. A novel approach for stabilizing fresh urine by calcium hydroxide addition. Water Res. 2016, 95, 361-369. [CrossRef]

8. Vilela, M.O.; Gates, R.S.; Souza, C.F.; Teles Junior, C.G.S.; Sousa, F.C. Nitrogen transformation stages into ammonia in broiler production: Sources, deposition, transformation, and emission into the environment. Dyna 2020, 87, 221-228. [CrossRef]

9. Simha, P.; Friedrich, C.; Randall, D.G.; Vinnerås, B. Alkaline Dehydration of Human Urine Collected in Source-Separated Sanitation Systems Using Magnesium Oxide. Front. Environ. Sci. 2021, 8, 619901. [CrossRef]

10. Krajewska, B.; Ureases, I. Functional, catalytic and kinetic properties: A review. J. Mol. Catal. B Enzym. 2009, 59, 9-21. [CrossRef]

11. Shaw, W.H.R.; Bordeaux, J.J. The decomposition of Urea in aqueous media. J. Am. Chem. Soc. 1955, 77, 4729-4733. [CrossRef]

12. Hocking, M.B. Ammonia, Nitric Acid and Their Derivatives. In Handbook of Chemical Technology and Pollution Control; Academic Press: Cambridge, MA, USA, 2006; pp. 321-364.

13. Bremner, J.M. Recent research on problems in the use of urea as a nitrogen fertilizer. Fertil. Res. 1995, 42, 321-329. [CrossRef]

14. Biskupski, A.; Mieczyslaw, B.; Dawidowicz, M.; Igras, J.; Kowalski, Z.; Kruk, J.; Malinowski, P.; Mozenski, C.; Myka, A.; Rusek, P.; et al. Method and Plant for Continuous Manufacture of Granular USP Nitrogen and Phosphate Type Fertilizers and Products on Their Basis. EP Patent No. 2774907-A2, 10 September 2014.

15. Gittenait, M. Reaction of Phosphoric Acid, Urea, and Ammonia. U.S. Patent No. 3713802A, 30 January 1973.

16. Young, D.C. Method of Producing Urea-Sulfuric Acid Reaction Products. U.S. Patent No. 4397675A, 5 November 1981.

17. Tischer, S.; Börnhorst, M.; Amsler, J.; Schoch, G.; Deutschmann, O. Thermodynamics and reaction mechanism of urea decomposition. Phys. Chem. Chem. Phys. 2019, 21, 16785-16797. [CrossRef]

18. Schaber, P.M.; Colson, J.; Higgins, S.; Thielen, D.; Anspach, B.; Brauer, J. Thermal decomposition (pyrolysis) of urea in an open reaction vessel. Thermochim. Acta 2004, 424, 131-142. [CrossRef]

19. Wang, D.; Dong, N.; Niu, Y.; Hui, S. A Review of Urea Pyrolysis to ProduceNH3 Used for NOx Removal. J. Chem. 2019, 2019, 6853638. [CrossRef]

20. Tempelman, C.; Warning, N.; van Geel, J.; van Bommel, F.; Lamers, K.; Hashish, M.; Schippers, J.; Gundlach, M.; Luijendijk, E. An Infrared and thermal decomposition study on solid deposits originating from heavy-duty diesel SCR urea injection fluids. Reactions 2020, 1, 72-88. [CrossRef]

21. Chen, J.P.; Isa, K. Thermal Decomposition of Urea and Urea Derivatives by Simultaneous TG/(DTA)/MS. J. Mass Spectrom. Soc. Jpn. 1998, 46, 299-303. [CrossRef]

22. Alvarez, C.; Calo, L.; Romero, L.C.; García, I.; Gotor, C. An O-acetylserine(thiol)lyase homolog with L-cysteine desulfhydrase activity regulates cysteine homeostasis in Arabidopsis. Plant Physiol. 2010, 152, 656-669. [CrossRef]

23. Lucheta, A.R.; Lambais, M.R. Sulfur in agriculture. Rev. Bras. Ciência Solo 2012, 36, 5. [CrossRef] 
24. Havlin, J.L.; Tisdale, S.L.; Nelson, W.L.; Beaton, J.D. Soil Fertility and Fertilizers, 8th ed.; Pearson: London, UK, 2017.

25. Fotyma, M.; Hammond, L.; Kesik, K. Suitability of North Carolina natural phosphate to Polish agriculture, in Fertilizers and Environment. Dev. Plant Sail Sci. 1996, 66, 151-154.

26. Ebner, H.; Wilsberg, S.S. Vinegar, Acetic Acid Production. In Encyclopedia of Bioprocess Technology: Fermentation, Biocatalysis and Bioseparation; Wiley-Interscience: Hoboken, NJ, USA, 1999; p. 2798.

27. Adam, N.; Mitchell, J.L.; Pickering, K.D. Development of low-toxicity urine stabilization for spacecraft water recovery systems. In Proceedings of the International Conference on Environmental Systems (ICES), Vail, CO, USA, 14-18 July 2013.

28. Kolomazník, K.; Langmaier, F.; Mládek, M.; Janáčová, D.; Taylor, M.M. Experience in Industrial Practice of Enzymatic Dechromation of Chrome Shavings. J. Am. Leather Chem. Assoc. 2000, 95, 55-63. 